\author{
P. Ylipaasto $\cdot$ B. Kutlu $\cdot$ S. Rasilainen $\cdot$ J. Rasschaert $\cdot$ \\ K. Salmela $\cdot$ H. Teerijoki $\cdot$ O. Korsgren $\cdot$ R. Lahesmaa $\cdot$ \\ T. Hovi · D. L. Eizirik · T. Otonkoski · M. Roivainen
}

\title{
Global profiling of coxsackievirus- and cytokine-induced gene expression in human pancreatic islets
}

Received: 24 February 2005 / Accepted: 29 March 2005 / Published online: 1 July 2005

(C) Springer-Verlag 2005

\begin{abstract}
Aims/hypothesis: It is thought that enterovirus infections initiate or facilitate the pathogenetic processes leading to type 1 diabetes. Exposure of cultured human islets to cytolytic enterovirus strains kills beta cells after a protracted period, suggesting a role for secondary virusinduced factors such as cytokines. Methods: To clarify the molecular mechanisms involved in virus-induced beta cell destruction, we analysed the global pattern of gene
\end{abstract}

Electronic Supplementary Material Supplementary material is available for this article at http://dx.doi.org/10.1007/s00125005-1839-7.

P. Ylipaasto · T. Hovi · M. Roivainen $(\bowtie)$

Enterovirus Laboratory, Department of Viral

Diseases and Immunology,

National Public Health Institute,

Mannerhcimintie 166,

00300 Helsinki, Finland

e-mail: merja.roivainen@ktl.fi

Tel.: +358-9-47448406

Fax: +358-9-47448355

B. Kutlu · J. Rasschaert · D. L. Eizirik Laboratory of Experimental Medicine, Université Libre de Bruxelles (ULB),

Bruxelles, Belgium

S. Rasilainen · T. Otonkoski

Hospital for Children and Adolescents and Program

of Developmental and Reproductive Biology,

Biomedicum, University of Helsinki,

Helsinki, Finland

K. Salmela

Renal Transplant Unit,

Helsinki University Hospital,

Helsinki, Finland

H. Teerijoki · R. Lahesmaa

Turku Centre for Biotechnology,

University of Turku and Åbo Akademi University,

Turku, Finland

O. Korsgren

Uppsala University Hospital,

Uppsala, Sweden expression in human islets. After $48 \mathrm{~h}$, RNA was extracted from three independent human islet preparations infected with coxsackievirus B5 or exposed to interleukin $1 \beta$ $(50 \mathrm{U} / \mathrm{ml})$ plus interferon $\gamma(1,000 \mathrm{U} / \mathrm{ml})$, and gene expression profiles were analysed using Affymetrix HGU133A gene chips, which enable simultaneous analysis of 22,000 probe sets. Results: As many as 13,077 genes were detected in control human islets, and 945 and 1293 single genes were found to be modified by exposure to viral infection and the indicated cytokines, respectively. Four hundred and eighty-four genes were similarly modified by the cytokines and viral infection. Conclusions/ interpretation: The large number of modified genes observed emphasises the complex responses of human islet cells to agents potentially involved in insulitis. Notably, both cytokines and viral infection significantly $(p<0.02)$ increased the expression of several chemokines, the cytokine IL-15 and the intercellular adhesion molecule ICAM-1, which might contribute to the homing and activation of mononuclear cells in the islets during infection and/or an early autoimmune response. The present results provide novel insights into the molecular mechanisms involved in viral- and cytokine-induced human beta cell dysfunction and death.

Keywords CBV-5 - Coxsackievirus - Diabetes mellitus · Interferon- $\gamma \cdot$ Interleukin $1 \beta \cdot$ Microarray analysis · Pancreatic beta cells Pancreatic islets

Abbreviations ADAR: adenosine deaminase, RNAspecific - ATF-3: activating transcription factor 3 - ATF-4 and -5: activating transcription factor 4 (tax-responsive enhancer element B67) and 5 - BAX: BCL2-associated X protein - CASP1, 4, 7, 8 and 10: apoptosis-related cysteine protease 1 (interleukin $1 \beta$, convertase) $4,7,8$ and 10 . CBV: coxsackievirus B - CCL3, 4, 5, 7, 8 and 22: chemokine (C-C motif) ligand 3 (MIP-1 $\alpha$ ), 4 (MIP-1 $\beta$ ), 5 (RANTES), 7 (MCP3), 8 (MCP2) and 22 - cig5: viperin CX3CL1: chemokine (C-X3-C motif) ligand 1

(fractalkine) - CXCL1, 2, 3, 5, 9, 10 and 11: chemokine (C$\mathrm{X}-\mathrm{C}$ motif) ligand 1 (melanoma growth stimulating 
activity $\alpha$ ), 2 (MIP-2), 3 (GROg), 5 (ENA-78), 9 (MIG), 10 (IP-10) and 11 (ITAC) - dsRNA: double-stranded RNA . FAIM: Fas apoptotic inhibitory molecule $\cdot$ G1P2: interferon $\alpha$-inducible protein (clone IFI-15K) · G1P3: interferon $\alpha$-inducible protein (clone IFI-6-16) - IA2: protein tyrosine phosphatase, receptor type, N (PTPRN) IAR: protein tyrosine phosphatase, receptor type, $\mathrm{N}$ polypeptide 2 (PTPRN2) - ICA69: islet cell autoantigen 1 . ICAM-1: intercellular adhesion molecule 1 (CD54), human rhinovirus receptor - IFI35 and 44: interferon-induced proteins 35 and 44 - IFI16: interferon $\gamma$-inducible protein 16 - IFI27: interferon $\alpha$-inducible protein $27 \cdot$ IFIT1: 2 and 4 interferon-induced protein with tetratricopeptide repeats 1, 2 and 4 - IFITM1: interferon-induced transmembrane protein 1 (9-27) - IFNB1: interferon $\beta 1$, fibroblast . IKBKE: inhibitor of kappa light polypeptide gene enhancer in beta cells, kinase epsilon - IL-6 and -15: interleukins 6 (interferon $\beta 2$ ) and 15 - IL-15RA: interleukin 15 receptor $\alpha \cdot$ IL1RN: interleukin 1 receptor antagonist $\cdot$ IL-4R: interleukin 4 receptor - INOS: nitric oxide synthase $2 \mathrm{~A}$ (NOS2A) - IRF: interferon regulatory factor - JAK2: Janus kinase 2 (a protein tyrosine kinase) - LFA-1: integrin $\beta 2$. MX1 and 2: myxovirus (influenza virus) resistance factors 1 and $2 \cdot$ NFKBIA: nuclear factor of kappa light polypeptide gene enhancer in beta cells inhibitor $\alpha$. NKX3-1: NK3 transcription factor related, locus 1 (Drosophila) · NMI: N-myc (and STAT) interactor · OAS 1, 2 and 3: 2',5'-oligoadenylate synthetases $1(40 / 46 \mathrm{kDa}), 2$ $(69 / 71 \mathrm{kDa})$ and $3(100 \mathrm{kDa}) \cdot$ PRKR: protein kinase, interferon-inducible double-stranded RNA-dependent . PVRL2: poliovirus receptor-related protein 2 (herpesvirus entry mediator B) · RIG-I: DEAD/H (Asp-Glu-Ala-Asp/ His) box polypeptide $\cdot$ STAT-1, 2 and 5A: signal transducer and activator of transcription $1(91 \mathrm{kDa}), 2(113 \mathrm{kDa})$ and 5A - TBK1: TANK-binding kinase 1 - TEGT: testis enhanced gene transcript (BAX inhibitor 1) - TLR-3: tolllike receptor 3

\section{Introduction}

Beta cell loss in type 1 diabetes mellitus results from a multifactorial process, involving host genes, environmental factors and an autoimmune response. Local inflammation within the islets (insulitis) leads to the release of proinflammatory and potentially cytotoxic cytokines such as IL-1 $\beta$ and IFN- $\gamma$ in the immediate vicinity of beta cells, contributing to progressive beta cell loss [1]. On top of the strong genetic component, environmental factors contribute to type 1 diabetes epidemiology. Common enterovirus infections, probably together with other environmental factors, appear to have a role in triggering insulitis and eventually clinical type 1 diabetes [2-7]. Viral infection has recently been suggested as the causative agent for the new form of 'type 1-like' diabetes mellitus in Japan [8]. The disease is characterised by an acute onset of diabetes with absence of beta cell autoantibodies, and it is often associated with flu-like symptoms [8].
Enterovirus infection usually starts from the respiratory or gastrointestinal mucosa, spreads through the lymphatics to the circulation, and after a brief viraemic phase localises into secondary replication sites in specific tissues and organs. Coxsackieviruses are capable of infecting human pancreas [2,9], and recent in situ hybridisation studies on post mortem pancreatic specimens of type 1 diabetes patients revealed enterovirus-positive cells exclusively in islet cells [9]. In prospective seroepidemiological studies, several enteroviruses have been associated with type 1 diabetes $[4,5,10-12]$. Likewise, cultured primary human beta cells are highly susceptible to infections caused by several enterovirus serotypes, representing different genetic subgroups and known to act through a number of different receptor families [9]. Of note, even the most cytolytic enterovirus strains kill beta cells only after several days in culture [13, 14], suggesting a role for cytokines or other secondary virus-induced factors in the process.

As a whole, the results described above suggest that a direct effect induced by virus infection might be responsible for islet beta cell destruction and subsequent insulitis. It remains to be defined, however, which are the molecular mechanisms involved in viral-induced beta cell damage and the consequent attraction of immune-competent cells to the islets. To address this question, we used microarray technology to analyse the global pattern of gene expression by human pancreatic islets infected with coxsackievirus B5 (CBV-5). The cells were harvested after $48 \mathrm{~h}$ of infection to allow time for the activation of key gene networks involved in the cellular response to the virus. Since our working hypothesis was that a viral infection may be followed by insulitis in genetically predisposed individuals, we analysed for comparison the general pattern of gene expression induced in these cells by the cytokines IL- $1 \beta$ plus IFN- $\gamma$, potential mediators of $\beta$-cell dysfunction and death during insulitis [1].

\section{Subjects, materials and methods}

Human pancreatic islets Human pancreatic islets were isolated from three donors (one female and two males) and purified at the Uppsala University Hospital (coordinator, Prof. Olle Korsgren) as previously described [15], with the consent of the ethics committee of Uppsala University. The donor age varied between 45 and 74 years and cold ischaemia time between $6 \mathrm{~h}$ and $8 \mathrm{~h} 54 \mathrm{~min}$. The islets were then sent to Helsinki as free-floating islets after 1-5 days of culture in Ham's F10 medium supplemented with $10 \mathrm{mmol} / \mathrm{l} \mathrm{HEPES}$ and $2 \%$ calf serum. Before the experiments, the islets were maintained for 1-3 days in sterile, non-adherent culture plates in serum-free incubation medium (Ham's F10 containing 25 mmol/l HEPES, pH 7.4, $1 \%$ bovine serum albumin, penicillin and streptomycin). The proportions of beta and alpha cells in the human islet preparations were $54-64 \%$ and $18-25 \%$, respectively, as determined by immunohistochemistry (see below). For the 
experiments, the islet cultures were divided into three parallel aliquots and were infected with CBV-5, exposed to cytokines or left untreated. The islet cell studies were approved by ethics committees both in Finland (The Institutional Review Board) and Sweden (ethical committee of Uppsala University).

Virus infection and cytokine exposure The prototype strain Faulkner of CBV-5, obtained from the American Type Culture Collection (Manassas, VA, USA), was passaged twice in a continuous cell line of monkey kidney origin (GMK).

The free-floating islets were infected with an apparent high multiplicity of CBV-5 (multiplicity of infection 30100), which enabled the maximal amount of islet cells to be infected simultaneously [13]. After adsorption for $1 \mathrm{~h}$ at $36^{\circ} \mathrm{C}$, the inoculum virus was removed and the cells were washed twice with Hanks' balanced salt solution supplemented with $20 \mathrm{mmol} / \mathrm{l}$ HEPES, $\mathrm{pH}$ 7.4. Serum-free incubation medium was added to all cultures, including cytokine-treated and uninfected controls. After adding IL$1 \beta(50 \mathrm{U} / \mathrm{ml})$ and IFN- $\gamma(1000 \mathrm{U} / \mathrm{ml})$ to the islets reserved for cytokine treatment, incubations of cell cultures of the three experimental groups were continued for $48 \mathrm{~h}$ at $36^{\circ} \mathrm{C}$. The concentrations of cytokines were selected on the basis of our previous studies on human islets $[16,17]$. At these concentrations, this cytokine combination induces functional impairment of human islets after 2-6 days [16] and apoptotic death of a fraction of the beta cells after 6-9 days $[17,18]$.

Analysis of mRNA expression by microarray analysis For microarray analysis, parallel sets of islets were harvested and total RNA was extracted using Trizol Reagent (Gibco BRL, Life Technologies, Gaithersburg, MD, USA). Further purification of RNA preparations was performed according to the RNeasy protocol for RNA cleanup with DNAse treatment (Qiagen, Valencia, CA, USA). Five microlitres of total precipitated RNA was used as the starting material for Affymetrix sample preparation. Samples were prepared according to the protocol provided by the manufacturer (Affymetrix, Santa Clara, CA, USA). Fifteen micrograms of biotin-labelled cRNA was fragmented and hybridised to HG-U133A array (Affymetrix).

The levels of mRNA expression of treated islets were compared with those of untreated control islets for each gene (or probe sets) present in the array. In order to maximise the information obtained by the study, data obtained in islets from each donor were analysed separately and by two complementary approaches.

First, according to Affymetrix recommendations, the probe set was excluded when: (1) considered absent in both target and reference genes; (2) if, in comparison analyses, the change call indicated no change; and (3) if the signal log ratio between the target and reference gene was between -1 and 1 . Accordingly, gene expression was considered to be modified by virus infection or cytokine exposure if the fold change was greater than or equal to 2 in all three experiments.
Secondly, all genes considered to be present by the Affymetrix software in at least three out of six experiments, i.e. 13077 genes, were analysed by statistical criteria (unpaired $t$-test against control) with $p<0.02$ as the cut-off point. After these two steps, we observed about 2800-3200 significantly modified probes in virus- and cytokine-treated islets (note that there might be several probes for the same gene). Taking into account the increased risk of an alpha error, inherent in multiple comparisons using the $t$-test, we estimate that, for $p<0.02$, around 260 of the genes detected as 'statistically different' ( $10 \%$ of the 'modified' genes) represent false positives. Considering the exploratory nature of the present work, we decided to accept this level of potential false positives. After this, and to further decrease false positives, we removed all genes whose expression was found to be modified to a statistically significant extent, but considered 'not changed' by the Affymetrix software in at least two out of three experiments. Finally, all genes considered as increased or decreased in all three individual experiments and showing a change greater than $50 \%$ compared with controls were also included in the analysis. This multistep approach was validated by empirical comparison against our previous candidate-gene analysis of human and rat islets exposed to cytokines $[1,19,20]$ and provided the final numbers of 945 and 1293 single genes modified by viral infection and cytokines, respectively. The agreement between the statistical and the Affymetrix approaches was 84 and $91 \%$ for virus- and cytokine-induced changes respectively. Data presented in the manuscript are preferentially based on the statistical criteria.

Annotation In order to assign the filtered genes to their respective functional clusters, we used our own Beta Cell Gene Expression Bank (http://t1dbase.org/cgi-bin/enter_bcgb. cgi). Genes not yet listed in the Beta Cell Gene Expression Bank were classified by manual gene-by-gene analysis, as previously described [19].

Real-time quantitative RT-PCR Real-time quantitative RTPCR was used to validate the microarray results. We used the TaqMan ABI Prism 7700 (Applied Biosystems, Foster City, CA, USA) as described before [21]. Primers and probes (see Electronic Supplementary Material, Table S1) used for the quantification of six selected genes (MedProbe, Oslo, Norway) were designed using Primer Express software (Applied Biosystems). Housekeeping gene GAPDH transcript was used as a reference. All measurements were performed in duplicate in two separate runs using samples derived from two biological replicates.

Cell viability The viability of islets exposed to CBV-5 or the proinflammatory cytokines IFN- $\gamma+\mathrm{IL}-1 \beta$ was measured 2 and 7 days after treatments using a commercial kit (Live/Dead assay L3224; Molecular Probes, Leiden, The Netherlands) and a confocal microscope (TCS NT; Leica, Wetzlar, Germany) [13]. 
Immunocytochemistry and nitrite determination Cytocentrifuged spots of samples of infected and uninfected islets were harvested 2 days after infection, fixed with methanol and double-stained with enterovirus-specific polyclonal rabbit antiserum and insulin-specific polyclonal sheep antiserum as previously described [13].

Nitrite concentration was measured as previously described [13].

\section{Results}

Purified islets from three human donors were each divided into three parallel aliquots and infected with CBV-5, treated with a mixture of IFN- $\gamma$ and IL-1 $\beta$, or kept as untreated controls. The virus replicated well in all three islet preparations, with maximum titres obtained already after 1 day (Fig. 1a). Several of the insulin-producing beta cells were infected 2 days after viral exposure, as shown by positive staining for both virus- and insulin-specific antisera (Fig. 1b). The first morphological changes in CBV-5-infected islets were evident 2 days after infection when assessed by light microscope. Progression of virus-induced cytolysis was evident 7 days after infection, when most nuclei of infected cells were stained red by ethidium homodimer-1, indicating cell death (Fig. 2). In contrast, islets exposed to cytokines still contained mostly viable cells at 2 and 7 days (Fig. 2).

Total RNA was extracted on day 2 from the parallel sets of islets exposed to either CBV-5, IFN- $\gamma+$ IL- $1 \beta$ or left untreated and used for cDNA and labelled cRNA pro-
Fig. 1 Coxsackievirus B5 (CBV-5) infection in human islets. a Samples taken at $0 \mathrm{~h}$ and 1 and 2 days after infection were assayed for total infectivity and results from three different experiments are shown as the mean \pm SD. The infectivity value indicated for $0 \mathrm{~h}$ after adsorption represents the residual of inoculum virus bound to the islet cells when the unbound virus was washed away. The subsequent increase in virus titre reflects virus replication in islets. The number of infectious units is higher 2 days after infection than at $0 \mathrm{~h}(p<0.02$, one-way ANOVA). b Cytocentrifuged spots of harvested cells were fixed with cold methanol ( 2 days after infection) and double-stained with enterovirusspecific rabbit antiserum and insulin-specific sheep antiserum. Visualisation was performed by fluorescein isothiocyanate-antirabbit (green, for virus antigen) and redX anti-sheep (red, for insulin) conjugates. Infected insulin-producing cells are yellow

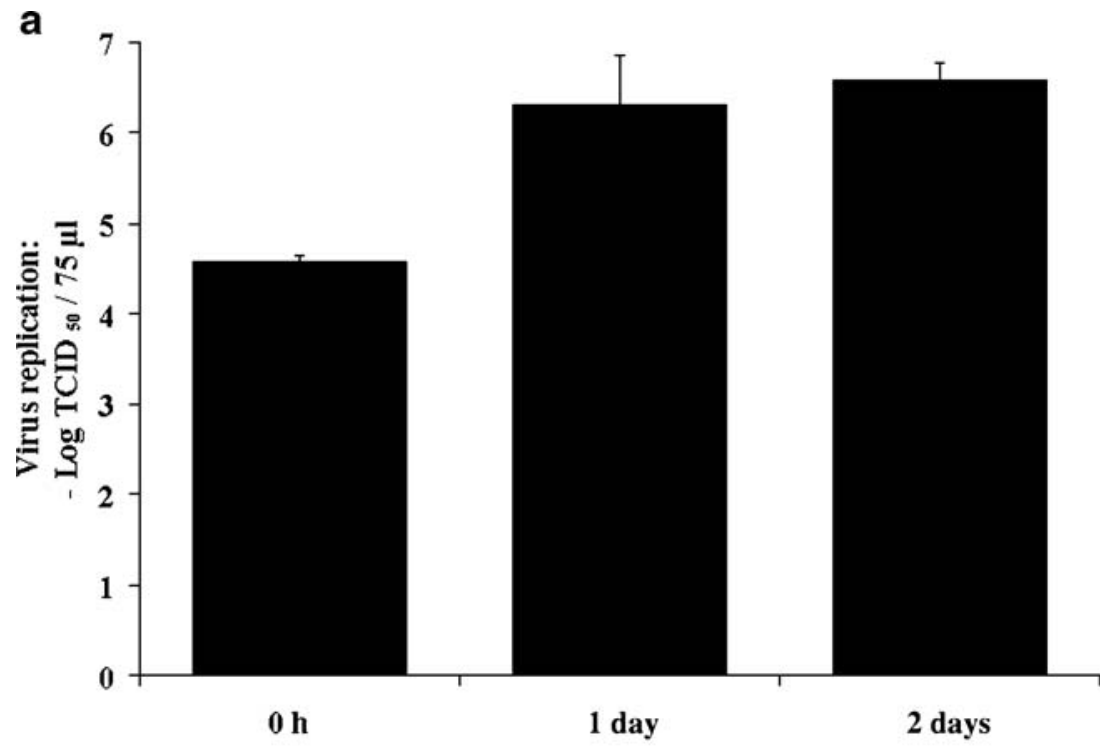

b

Control
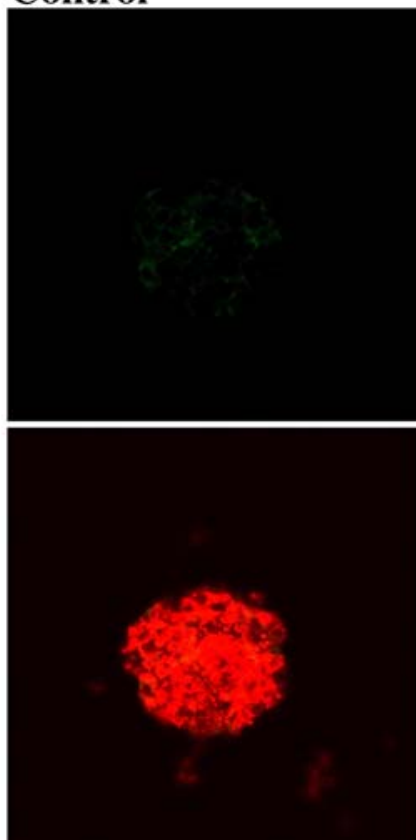

CBV-5

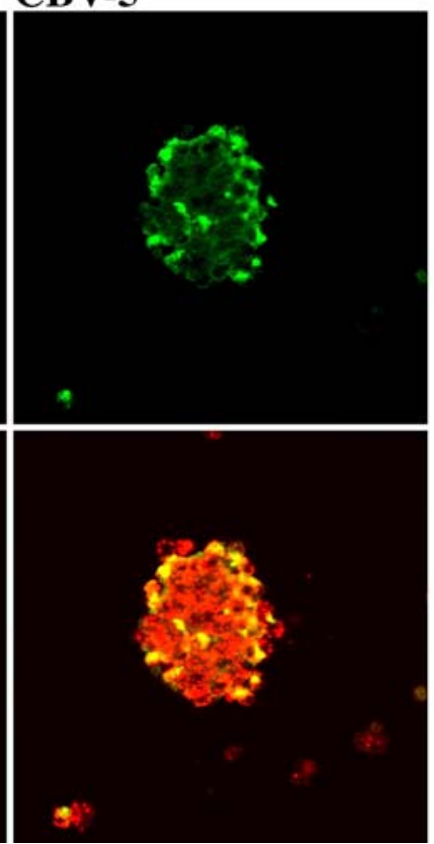

Virus

Virus, insulin 
Fig. 2 The viability of human islets infected with coxsackievirus B5 (CBV-5) or treated with cytokines IL-1 $\beta+$ IFN- $\gamma$. Samples taken 2 and 7 days after treatments were assayed for cell viability. In the assay, live cells were stained green by calcein because of their esterase activity, while red fluorescence was induced in the nuclei of dead cells by ethidium homodimer- 1 . Results from all three experiments are shown

Control
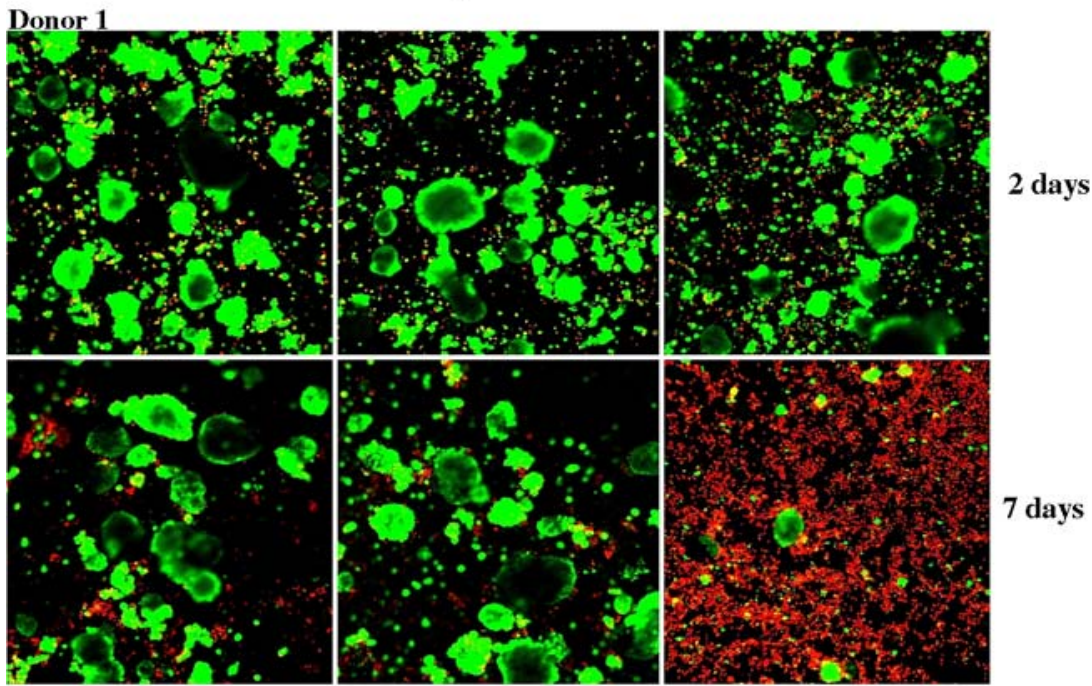

Donor 2
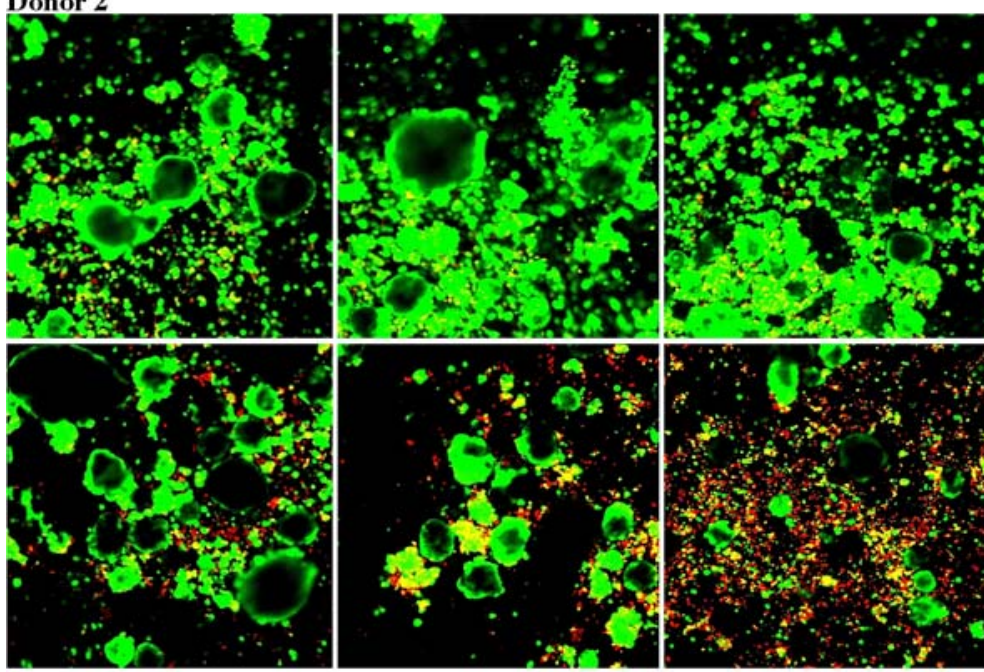

2 days
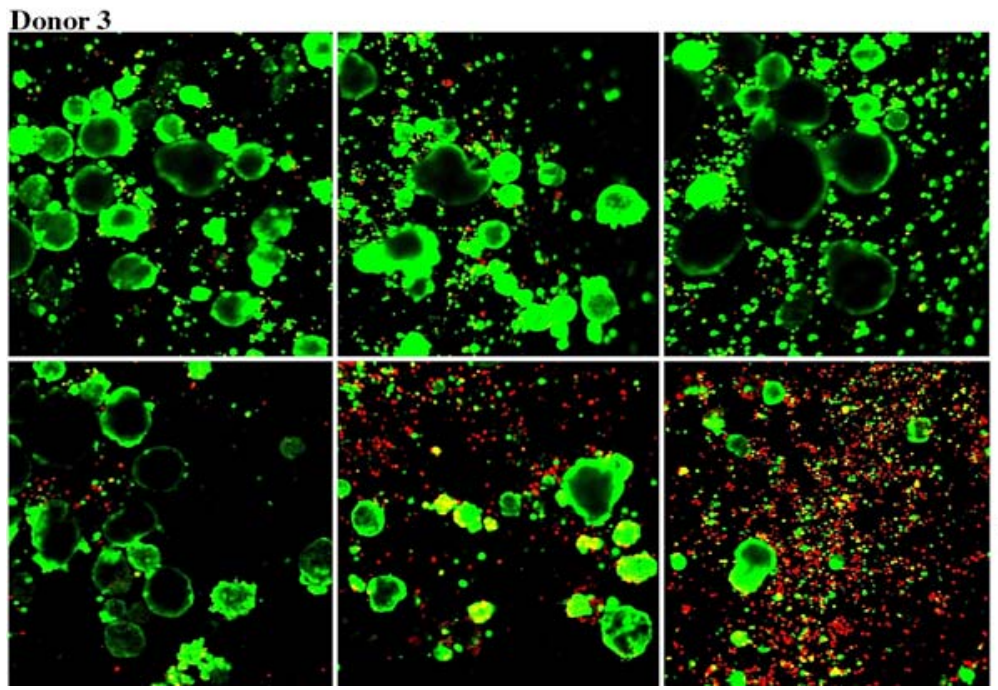

2 days

7 days

duction. The biotin-labelled cRNAs were hybridised to the Affymetrix human HG-U133A gene chips. Altogether, 13 077 genes were detected in control human islets. Of these,
945 and 1293 genes (with a unique LocusLink IDs) were modified in the three islet cell experiments by CBV-5 infection and cytokines, respectively. Four hundred and 
eighty-four genes were similarly modified by exposure to IFN- $\gamma+$ IL- $1 \beta$ or virus infection.

The complete list of all modified genes with annotations is shown as Electronic Supplementary Material (ESM, Tables S2 and S3). Genes that are represented by more than one probe set are shown only once, using the probe set that provided the most representative value for the different probe sets present in the array.

Functional clustering of modified genes Clusters of differentially expressed genes in human islets, together with individual numbers of up- and down-regulated genes in each cluster, after 2 days of exposure to CBV-5 or the cytokine mixture are shown in Fig. 3. The modifications induced by both conditions were mainly targeted to genes involved in protein synthesis, modification and secretion, metabolism, signal transduction, cell adhesion, and cellular defence and repair mechanisms. Slightly less than half of the modifications (CBV-5, 46\%; cytokines, 43\%) in gene expression represented up-regulation (Fig. 3a). The highest and most regularly found up-regulations were observed in genes encoding cytokines, chemokines and related receptors, various signal transduction molecules, and molecules involved in antiviral responses, cellular defence and repair, and immune responses (ESM, Tables S2-S3).

Genes related to inflammation In virally infected tissues, inflammation is initially coordinated by chemokines and cytokines, known to form an important network of the innate immune system. In human islets the expression of

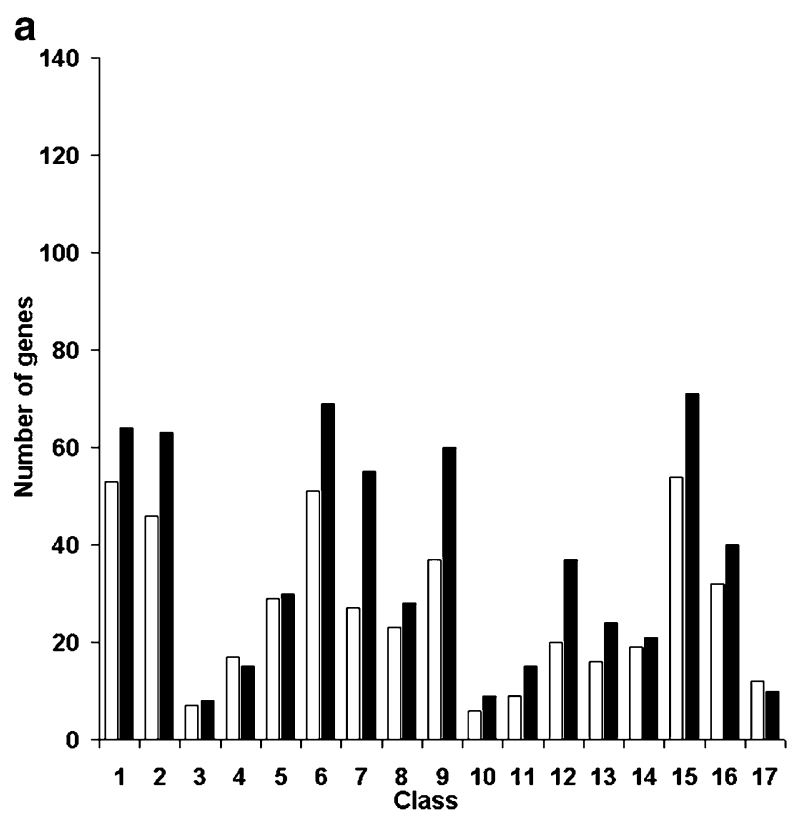

Fig. 3 Clusters of differentially expressed genes in human islets together with individual numbers of up-regulated (a) and downregulated (b) genes in each of the clusters after 2 days of exposure to CBV-5 or cytokines. Genes with multiple probes are counted only once. Open bars: virus-induced up- or down-regulation; filled bars: cytokine-induced up- or down-regulation. Gene clusters: 1, metabolism; 2, protein synthesis, modification and secretion; 3, ion channels, ion transporters and related proteins; 4 , hormones, growth several chemokines, such as CX3CL1 (fractalkine), CXCL1 (MIP-2 $\alpha$ ), CXCL2 (MIP-2 $\beta$ ), CXCL3 (GRO- $\gamma$ ), CXCL5 (ENA78), CXCL10 (IP-10), CXCL11 (I-TAC), CCL8 (MCP-2) and CCL5 (RANTES), the cytokine IL-15, and receptors IL-15RA and IL-4R were significantly increased $(p<0.02)$ by both cytokine exposure and CBV-5 infection (Fig. $4 \mathrm{a}-\mathrm{c}$ ). Viral infection, but not the cytokines, significantly up-regulated the expression of genes encoding CCL3 (MIP-1 $\alpha$ ) and CCL4 (MIP-1 $\beta$ ), IL-1 receptor antagonist and IFN- $\beta$, while only cytokine exposure induced CCL7 (MCP3) and CXCL9 (MIG) (Fig. 4a-c).

The expression level of genes encoding several cell adhesion molecules was changed in human islets infected with CBV-5 or exposed to IL- $1 \beta+$ IFN- $\gamma$ (ESM, Tables S2 and S3). The expression of intercellular adhesion molecule ICAM-1 and the poliovirus receptor-related protein 2 (PVRL-2) was significantly increased by both treatments. ICAM-1 is known to also act as a cellular receptor for some coxsackie A viruses and most rhinoviruses, while PVRL-2 is a protein involved in herpesvirus entry. In contrast, integrin $\alpha \mathrm{V}$, a component of the vitronectin receptor which also serves as a receptor for some enteroviruses in primary human islets [9], was specifically down-regulated by the cytokines.

Genes involved in defence, death and repair Toll-like receptors (TLR) are central components of antiviral defence. Among them, TLR-3 is specifically stimulated by the double-stranded RNA produced by most viruses during replication. In our experiments, TLR-3 was up-regulated by both

b

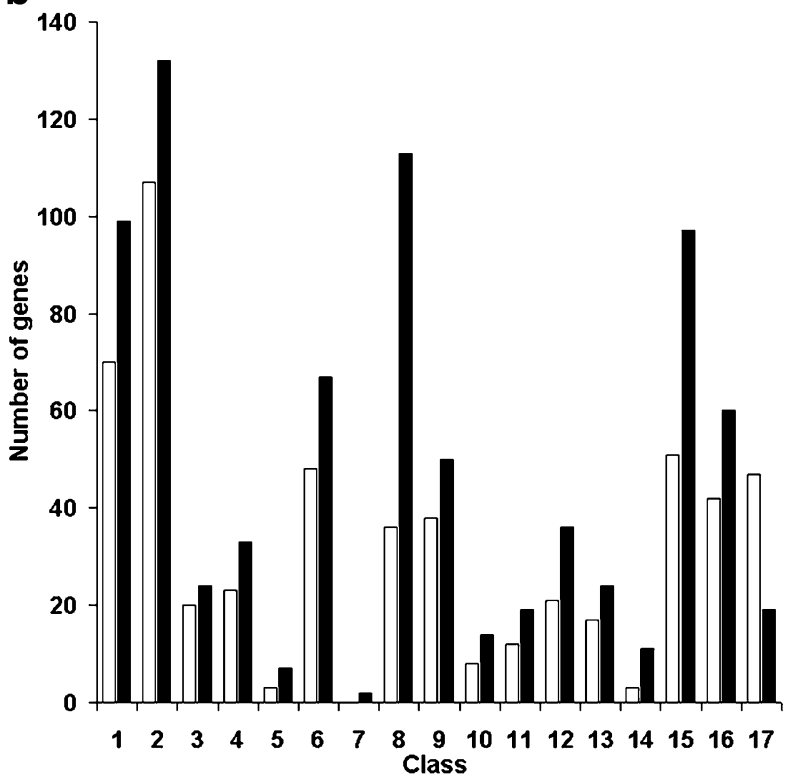

factors and related genes; 5, cytokines, chemokines and related receptors; 6, cytokine signal transduction; 7, MHC and related genes; 8, cell adhesion, cytoskeleton and related genes; 9, transcription factors and related proteins; 10, RNA synthesis, editing and splicing factors; 11, cell cycle; 12, defence/repair; 13, apoptosis and ER stress response and related genes; 14, antiviral response; 15, miscellaneous; 16, hypothetical proteins; 17 , not classified 
Fig. 4 Stimulation of genes involved in inflammation (a-c), transcription (d-e), and apoptosis and antiviral effects $(\mathbf{f}-\mathbf{g})$ by coxsackievirus B5 (CBV-5) and cytokines, IL- $1 \beta+$ IFN- $\gamma$, in human islets. The data shown on the histograms are based on ESM Tables S2 S3, but additional information is provided on genes induced by only one of the two treatments (shown in ESM Tables S1 or S2; also shown here for both conditions). Means of transcript-specific hybridisation signals obtained after normalisation are expressed as arbitrary units (AU). Open bars: control; striped bars: CBV-5; filled bars: cytokines
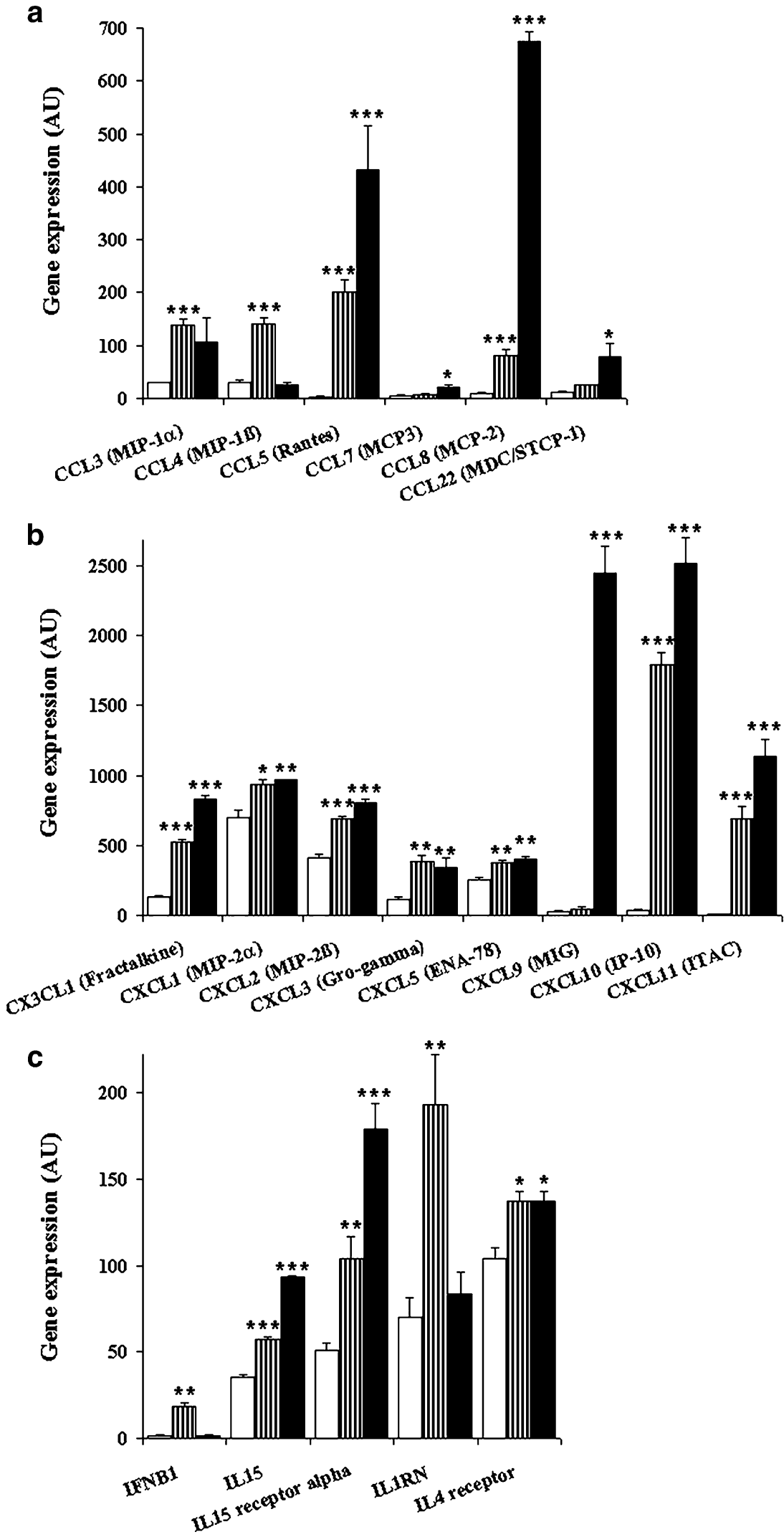

viral infection and cytokine treatment (Tables S2 and S3). Activation of TLR-3 usually results in stimulation of IKBrelated kinase and TBK-1 (TANK-binding kinase), leading to activation of transcription factors such as immune regulatory factor 3 (IRF-3) (regulated at the post-transcriptional level) [22, 23] and NFKB, which in turn results in 

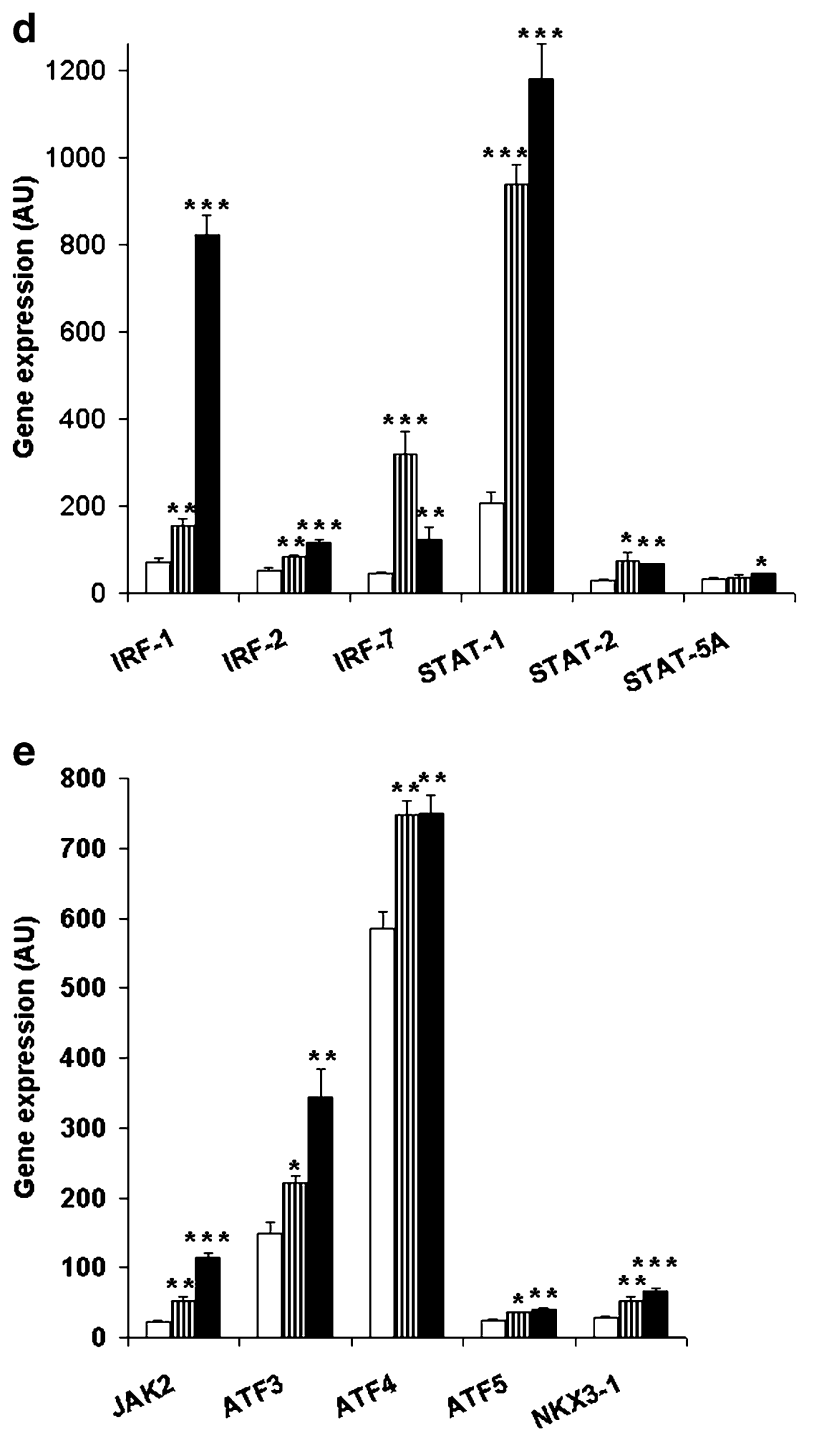

Fig. 4 (continued)

production of type 1 interferons. Secreted interferons activate Jak/STAT signalling pathways, resulting in the production of IRF-7, which in turn stimulates transcription of type 1 IFNs via a positive autocrine feedback mechanism [24]. In human islets, the expression of IKBKE and TBK-1 was induced by both viral infection and cytokines (ESM, Tables S2 and S3). Likewise, up-regulation of IFN- $\beta$ was seen in CBV-5-infected islets but not in the cytokine-treated islets (Fig. 4c). Expression of transcription factors IRF-1, -2 and -7 , which are transcriptional regulators for type 1 interferons [25-27], was up-regulated by both CBV-5 infection and the cytokine treatment (Fig. 4d). In agreement with our previous observation in rat beta cells exposed to double-stranded RNA (dsRNA) [28], there was more marked induction of IRF-7 by viral infection than by exposure to cytokines (Fig. 4d). Other transcription factors found to be stimulated by both virus and cytokines were STAT-1/2, ATF-3/4/5 and NKX3-1.

Anti-viral genes encoding MX proteins 1 and 2 (myxovirus resistance protein), OAS $1,2,3$ and L (2'-5'-oligo- adenylate synthetase), PKR (interferon-inducible doublestranded RNA-dependent protein kinase), ADAR (dsRNAspecific adenosine deaminase), viperin and DEAD/H box polypeptide (RIG-I) were drastically up-regulated in primary human islets by both virus infection and cytokine treatment (ESM, Tables S2 and S3), while CBV-5 infection increased expression of the IFN-beta gene.

Viruses can affect apoptosis in two ways: by inducing apoptosis of the host cell in order to facilitate progeny release from the cell and by inhibiting apoptosis to ensure continuous production of progeny viruses [29]. In human islets exposed to CBV-5 infection or cytokines, several proapoptotic molecules, such as caspases 1, 8 and 10, were up-regulated (Fig. 4g and Tables S2 and S3).

Nitric oxide, produced by the inducible form of nitric oxide synthase (iNOS), is an important mediator of rat and mouse beta cell death, but its role in cytokine-induced human beta cell death remains controversial [1]. In the present study the gene encoding iNOS (inducible nitric oxide synthase $2 \mathrm{~A}$ ) was drastically up-regulated by the mixture of cytokines but only marginally and insignificantly affected by CBV-5 infection (Fig. 5a). Nitrite concentrations were 8 - to 10 -fold higher in cytokine-treated islets than in untreated controls, but did not change following viral infection (Fig. 5b).

Genes related to islet cell autoantigens and antigen presentation Eleven MHC class I- and 13 class II-related genes were up-regulated by the cytokine exposure. After CBV-5 infection only five class I genes were up-regulated, including HLA-B, -E, -F, -G and -J (Tables S2 and S3). All these mRNAs were also induced by cytokines. No stimulation was found in class II genes after CBV-5 infection, whereas several of these genes were drastically up-regulated by the cytokine treatment. In contrast, expression of an MHC class II-associated gene, CD74, was increased after both treatments (ESM, Tables S2 and S3).

The expression level of glutamate decarboxylase (GAD1), a 67-kDa protein expressed mainly in brain, was induced 6-fold by cytokines, while GAD2, a $65-\mathrm{kDa}$ protein known to be expressed in both pancreatic islets and brain, was down-regulated by $50 \%$ after virus infection. Expression levels of other autoantigens previously associated with type 1 diabetes, such as insulin, sialoglycolipid, carboxypeptidase $\mathrm{H}$, tyrosine phosphatase IAR/IA2, ICA69 and sulphatide, were not changed in primary human islets infected with CBV-5 or treated with the mixture of cytokines.

Quantitative real-time PCR confirmation of selected microarray results Quantitative real-time PCR was used to confirm increases in mRNA expression in selected genes observed in the microarray analysis. The GAPDH housekeeping gene was used as a control. In good agreement with the microarray data, expression levels of CCL5, MX1, IRF1, CASP1, IFI16 and NMI were clearly increased after treatments with CBV-5 or cytokines (Fig. 6). 
Fig. 4 (continued)
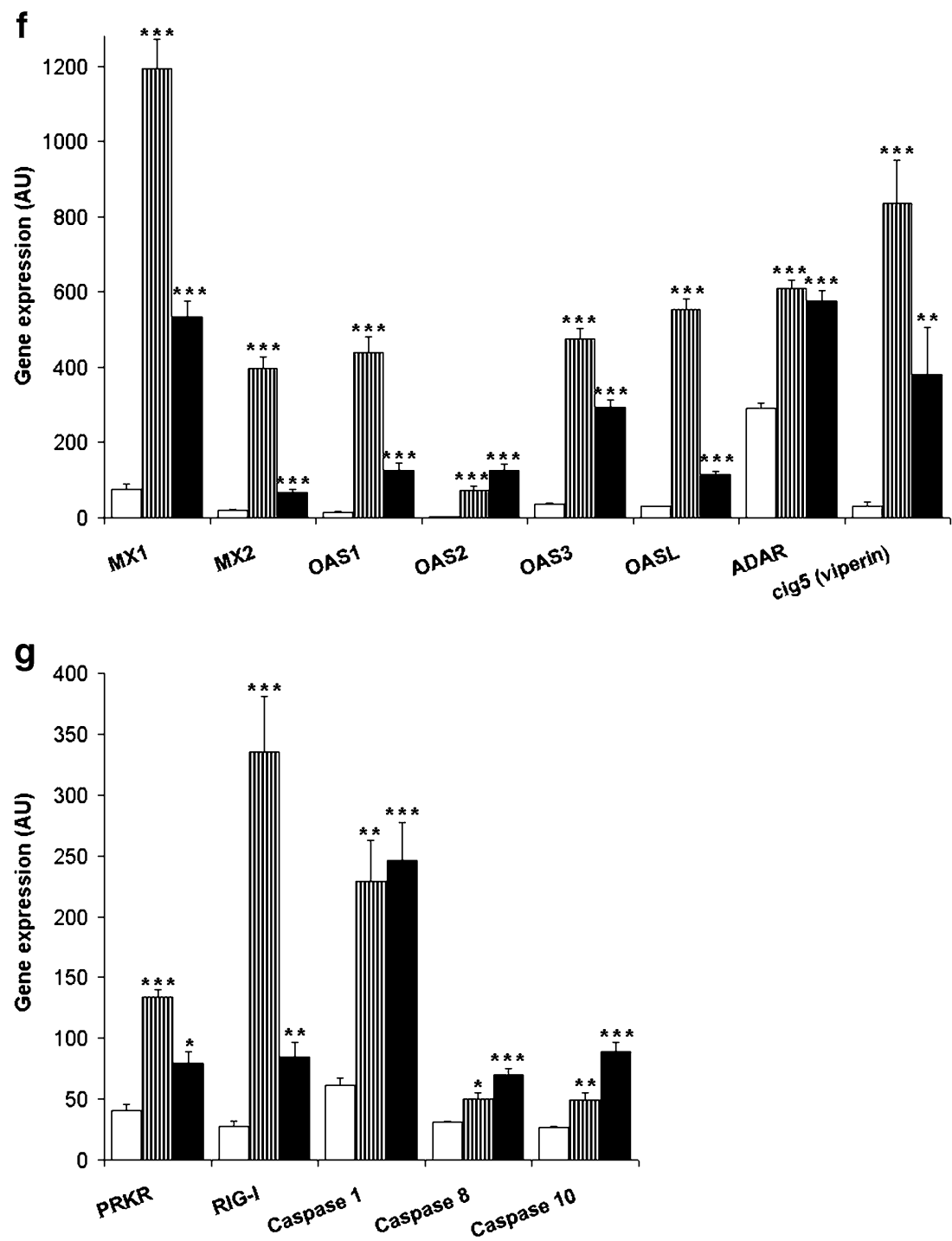

\section{Discussion}

The present study is the first attempt to define the global repertoire of genes expressed in human pancreatic islets infected with $\mathrm{CBV}-5$ or exposed to a combination of interleukin $1 \beta$ plus interferon $\gamma$, two cytokines known to participate in the immune assault against beta cells during insulitis [1]. Although we hypothesise that the first wave of CBV-5-induced beta cell dysfunction and destruction will trigger insulitis in genetically predisposed individuals, and hence local production of IL- $1 \beta$, IFN- $\gamma$ and other cytokines by invading mononuclear cells, this remains to be proven. Therefore, the present study does not allow direct subtractive analysis of putative gene activation cascades induced by virus infection or cytokine exposure, especially because the limited availability of human islets restricted our study to a single time point, namely after $48 \mathrm{~h}$ of exposure to the virus or the cytokine combination.

Human islets rather than purified beta cells were used in this study, and therefore part of the gene activity monitored could be derived from non-beta cells. However, we believe that a large proportion of the genes observed are expressed in beta cells because the CBV-5 strain used here is particularly efficient in infecting beta cells and the islet preparations used contained more than $54 \%$ beta cells. On the other hand, during true virus infection of islets in nature, the infection may also induce changes in non-beta cell genes that may be relevant in the pathogenesis of type 1 diabetes mellitus. CBV-5 was selected out of more than 65 enterovirus serotypes capable of infecting humans, based on our previous results indicating that this prototype strain is one of the most destructive serotypes primarily infecting human beta cells $[13,14]$ and on epidemiological studies supporting an association between CBV-5 infection and type 1 diabetes $[10,30,31]$. Because of space limitations, only some of the genes shown in Tables S2 and S3 are discussed here; additional information on some of these genes can be found in our previous publications dealing with microarray analysis of rat beta cells $[28,32]$.

Cell reactions to a viral infection include activation of antiviral defence pathways, commitment to apoptosis, and the production of specific cytokines. In some cases, virus 


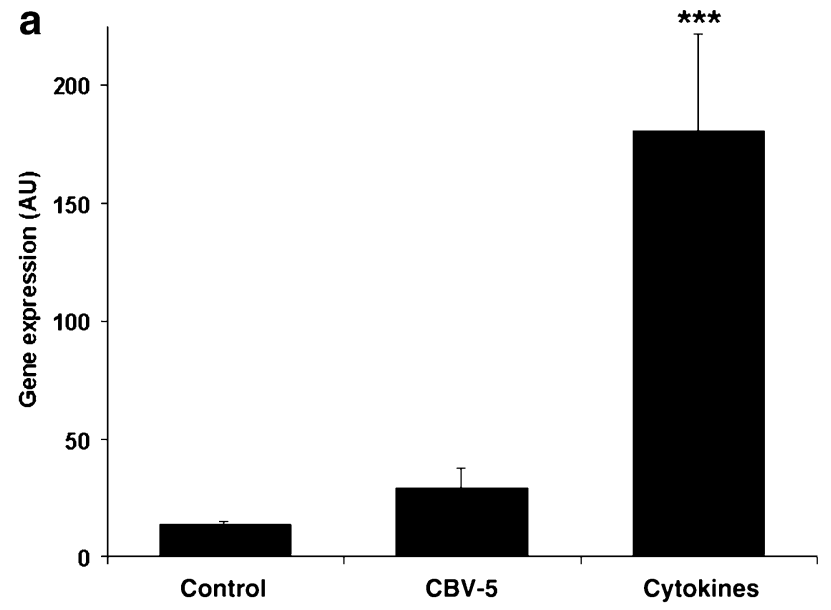

b

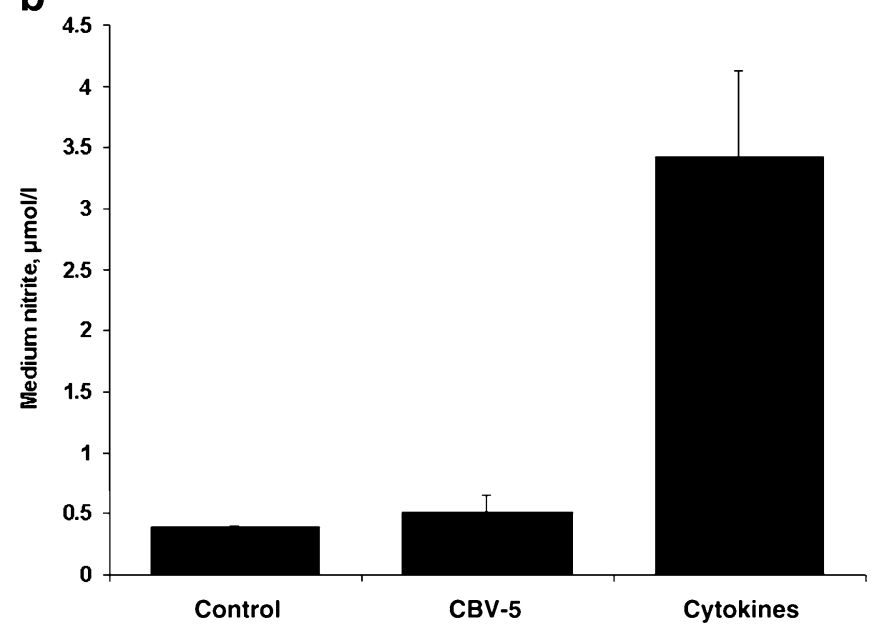

Fig. 5 Effect of coxsackievirus B5 (CBV-5) infection or cytokine treatment on expression level of inducible nitric oxide synthase (NOS2A) in human islets. a Expression level of the gene encoding NOS2A 2 days after treatments. b Nitrite concentrations in culture media of treated islets 2 days after treatments. At this early time point the number of islets was practically equal in the different cultures. Means of two different experiments are shown

binding to cellular receptor is enough to trigger a host cytokine response [33]. In primary human islets, infection with CBV-5 increased expression of chemotactic (fractalkine, RANTES, MIP- $2 \alpha$, IP-10, I-TAC, MIP- $2 \beta$, GRO- $\gamma$, RANTES, ENA 78) and proinflammatory (IL-6, IL-15) cytokines. Most of these genes were also activated by treatment with the proinflammatory cytokines IL- $1 \beta$ plus IFN- $\gamma$. In addition, both treatments stimulated caspase-1, previously known as ICE (IL- $1 \beta$-converting enzyme), which processes proIL-1 $\beta$, releasing its biologically active form [34]. RANTES and IP-10 are secondarily up-regulated by autocrine production of IFN- $\beta$ in most cell types [35], but exposure of primary rat beta cells to IFN- $\gamma$ and/or dsRNA also increases IP-10 and RANTES mRNA expression $[20,28]$. Increased IP-10 expression has also been observed in islets isolated from prediabetic NOD mice [20], during islet graft rejection [20] and in NOD-scid mice infused with islet-specific transgenic CD4 cells [36]. In- terestingly, certain RNA viruses capable of infecting the pancreas and causing diabetes also induce early and elevated pancreatic expression of IP-10 [37]. This suggests that virus-induced organ-specific autoimmune disease might depend on both virus tropism and on its ability to alter the local milieu by selectively inducing chemokines that target the infected tissue for subsequent destruction by the adaptive immune response [37].

Both CBV-5 infection and cytokine treatment stimulated expression of TLR- 3 and genes related to IFN- $\gamma$ signal transduction, including STAT-1. This is interesting since STAT-1 activation leads to antiproliferative and proapoptotic events in some cell types [38-40]. Likewise, islets or purified beta cells isolated from STAT1 ${ }^{-/}$mice are resistant to IL- $1 \beta+\mathrm{IFN}-\gamma$-induced cell death (C. Geysemans, L. Ladriere, H. Callewaert, J. Rasschaert, D. Flamez, D. E. Levy, P. Matthys, D. L. Eizirik and C. Mathieu, submitted for publication). Members of the IRF family participate in many aspects of the immune response [41]. For instance, IRF-7 and IRF-3 are involved in virus-induced expression of the cytokine IFN- $\alpha / \beta[24,42]$ and IFN- $\gamma$-mediated apoptosis [43].

IFN- $\alpha$, mainly produced by leucocytes, is a major antiviral cytokine, having both antiproliferative and immunomodulatory functions. We did not detect increased IFN- $\alpha$ in the present analysis, performed $48 \mathrm{~h}$ after viral infection, but expression of genes encoding IFN- $\alpha / \beta$-inducible proteins (MX1, OAS, IFI27, IFIT1, 2 and 4, IFITM 1, IFI 35, IFI 44 , etc.) were drastically up-regulated by $\mathrm{CBV}-5$ infection, suggesting that transient induction of IFN- $\alpha$ might have taken place at an earlier time point. In line with this possibility, rat beta cells exposed to dsRNA+ IFN- $\gamma$ show an early $(6 \mathrm{~h})$ and transient increase in IFN$\alpha$ expression, with return to baseline levels after $24 \mathrm{~h}$ (J. Rasschaert and D. L. Eizirik, manuscript in preparation). Alternatively, the gene up-regulations described above could be secondary to the IFN- $\beta$ induction observed.

Prolonged exposure of human beta cells to IL- $1 \beta+$ IFN- $\gamma$ culminates in apoptosis $[16,17]$, whereas most CBV-5-infected beta cells die by secondary necrosis after initial nuclear pyknosis [13]. Several similar proapoptotic and antiviral genes involved in cellular death, defence and repair were up-regulated by both treatments, suggesting that innate antiviral mechanisms in the infected beta cells attempt to restrict virus replication at early stages of infection [44]. This response is probably effective in most individuals, allowing them to eradicate the infecting viruses without excessive beta cell loss. In other individuals however, an exacerbated local inflammatory response, together with the viral infection, will lead to progressive beta cell loss, amplification of the immune response and eventually progression to diabetes mellitus.

The present results provide the first global information on the complex nature of the response of human islet cells to infection by a potential diabetogenic virus. The data obtained raise the intriguing possibility that susceptibility to type 1 diabetes might depend on the genetically regulated and combined expression of dozens of genes that participate in the beta cell response to a viral infection. 
a

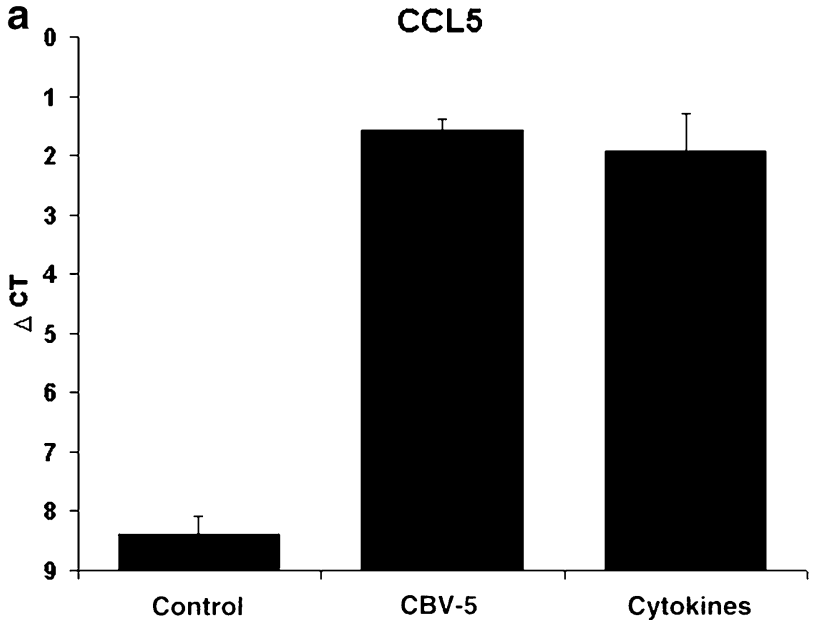

C

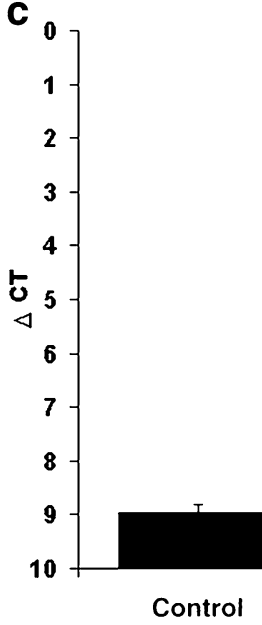

e

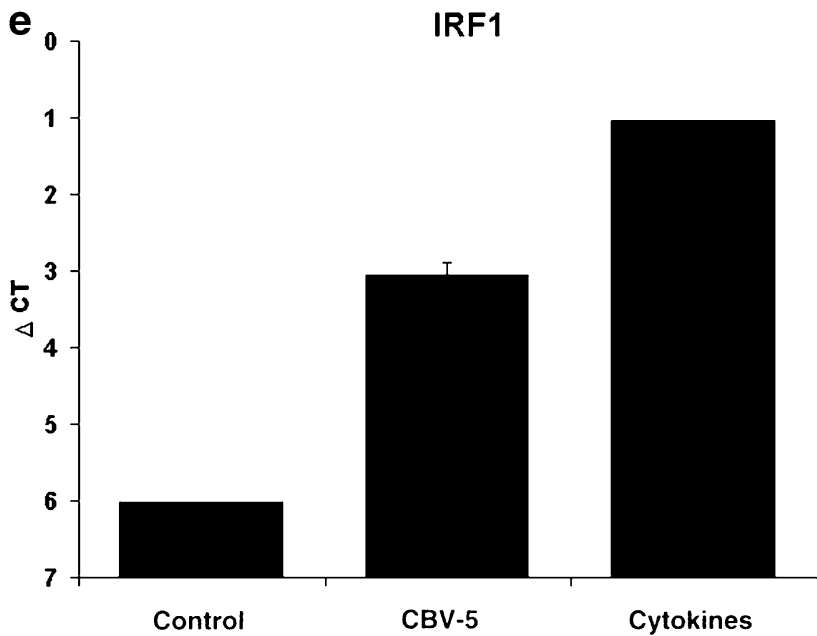

Fig. 6 Quantitative real-time PCR results for expression levels of selected islet cell genes $(\mathbf{a}-\mathbf{f})$. RNAs isolated from two donors after CBV-5 or cytokine treatments were analysed. Gene expression signals $(\triangle \mathrm{CT})$ in relation to the housekeeping gene GAPDH are shown (minimum 40; maximum $=>0$ ). CCL5, chemokine ( $\mathrm{C}-\mathrm{C}$ motif) ligand 5 (RANTES) (a); CASP1, caspase 1, apoptosis-related cys-
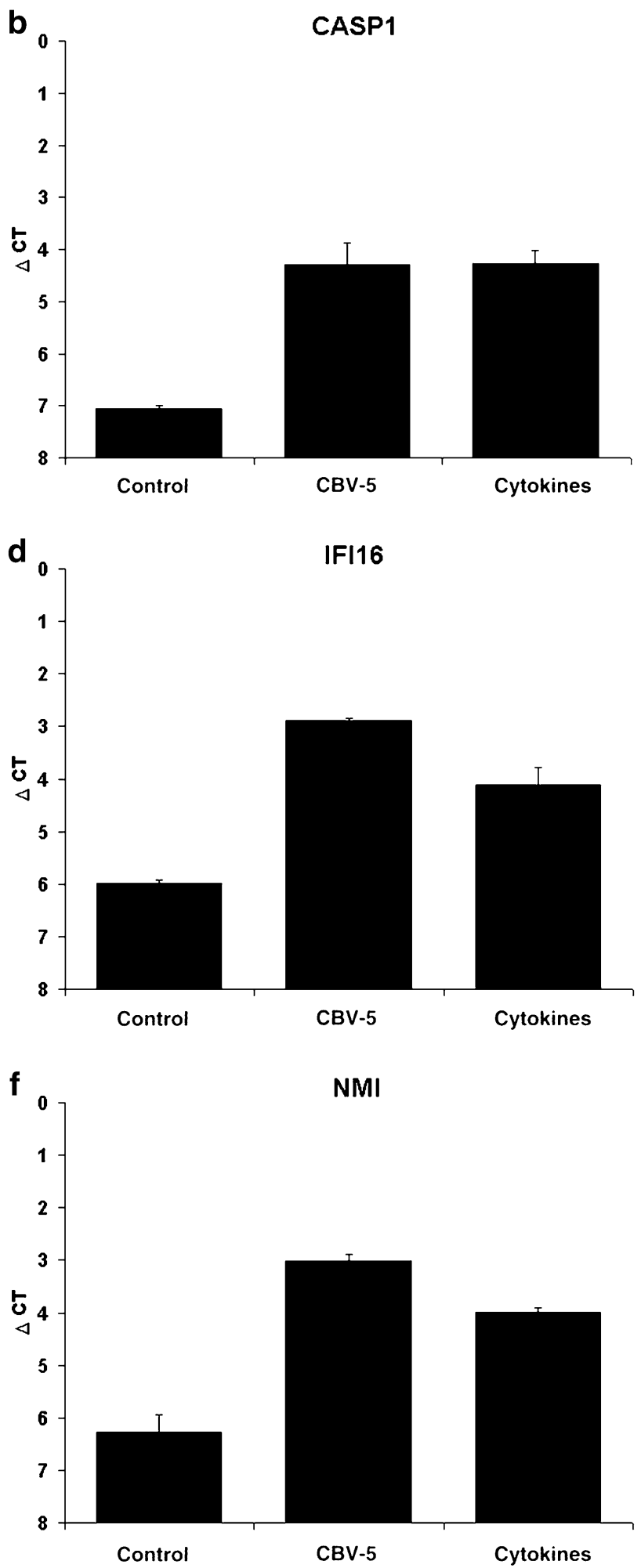

teine protease (interleukin 1 beta, convertase) (b); MX1, myxovirus (influenza virus) resistance protein 1 , interferon-inducible protein p78 (mouse) (c); IFI16, interferon, gamma-inducible protein 16 (d); IRF-1, interferon regulatory factor 1 (e); NMI, N-myc (and STAT) interactor (f). Means of two preparations are shown 
Acknowledgements The authors wish to thank Ms Mervi Eskelinen, Ms Marjo Linja, Ms Miina Miller and the Finnish DNA Microarray Centre at Turku Centre for Biotechnology for skilful technical assistance. This study was supported by the Finnish Diabetes Research Foundation and a partnership grant from the Academy of Finland, the Sigrid Juselius Foundation and The Juvenile Diabetes Research Foundation International (to $M$. Roivainen and T. Otonkoski), the Academy of Finland (to R. Lahesmaa and $\mathrm{H}$. Teerijoki) and by grants from the European Foundation for the Study of Diabetes/Novo Nordisk Programme in Diabetes Research, Action de Recherche Concertées (ARC) de la Communauté Française, Belgium and the Fonds National de la Recherche Scientifique (FNRS), Belgium (D. L .Eizirik. and J. Rasschaert). This work was conducted in collaboration with and partially supported by the JDRF Center for Prevention of Beta Cell Destruction in Europe under grant number 4-2002-457 (D. L. Eizirik).

\section{References}

1. Eizirik DL, Mandrup-Poulsen T (2001) A choice of death-the signal-transduction of immune-mediated beta-cell apoptosis. Diabetologia 44:2115-2133

2. Yoon JW, Austin M, Onodera T, Notkins AL (1979) Isolation of a virus from the pancreas of a child with diabetic ketoacidosis. N Engl J Med 300:1173-1179

3. Helfand RF, Gary HE Jr, Freeman CY, Anderson LJ, Pallansch MA (1995) Serologic evidence of an association between enteroviruses and the onset of type 1 diabetes mellitus. Pittsburgh Diabetes Research Group. J Infect Dis 172:12061211

4. Hyoty H, Hiltunen M, Knip M et al (1995) A prospective study of the role of coxsackie $\mathrm{B}$ and other enterovirus infections in the pathogenesis of IDDM. Childhood Diabetes in Finland (DiMe) Study Group. Diabetes 44:652-657

5. Hiltunen M, Hyoty H, Knip M et al (1997) Islet cell antibody seroconversion in children is temporally associated with enterovirus infections. Childhood Diabetes in Finland (DiMe) Study Group. J Infect Dis 175:554-560

6. Clements GB, Galbraith DN, Taylor KW (1995) Coxsackie B virus infection and onset of childhood diabetes. Lancet 346: 221-223

7. Dahlquist GG, Ivarsson S, Lindberg B, Forsgren M (1995) Maternal enteroviral infection during pregnancy as a risk factor for childhood IDDM. A population-based case-control study. Diabetes 44:408-413

8. Imagawa A, Hanafusa T, Uchigata Y et al (2003) Fulminant type 1 diabetes: a nationwide survey in Japan. Diabetes Care 26:2345-2352

9. Ylipaasto P, Klingel K, Lindberg AM et al (2004) Enterovirus infection in human pancreatic islet cells, islet tropism in vivo and receptor involvement in cultured islet beta cells. Diabetologia 47:225-239

10. Roivainen M, Knip M, Hyoty H et al (1998) Several different enterovirus serotypes can be associated with prediabetic autoimmune episodes and onset of overt IDDM. Childhood Diabetes in Finland (DiMe) Study Group. J Med Virol 56:74-78

11. Craig ME, Howard NJ, Silink M, Rawlinson WD (2003) Reduced frequency of HLA DRB $1 * 03-\mathrm{DQB} 1 * 02$ in children with type 1 diabetes associated with enterovirus RNA. J Infect Dis 187:1562-1570

12. Cabrera-Rode E, Sarmiento L, Tiberti C et al (2003) Type 1 diabetes islet associated antibodies in subjects infected by echovirus 16. Diabetologia 46:1348-1353

13. Roivainen M, Rasilainen S, Ylipaasto P et al (2000) Mechanisms of coxsackievirus-induced damage to human pancreatic beta cells. J Clin Endocrinol Metab 85:432-440
14. Roivainen M, Ylipaasto P, Savolainen C, Galama J, Hovi T, Otonkoski T (2002) Functional impairment and killing of human beta cells by enteroviruses: the capacity is shared by a wide range of serotypes, but the extent is a characteristic of individual virus strains. Diabetologia 45:693-702

15. Johansson U, Olsson A, Gabrielsson S, Nilsson B, Korsgren O (2003) Inflammatory mediators expressed in human islets of Langerhans: implications for islet transplantation. Biochem Biophys Res Commun 308:474-479

16. Eizirik DL, Sandler S, Welsh N et al (1994) Cytokines suppress human islet function irrespective of their effects on nitric oxide generation. J Clin Invest 93:1968-1974

17. Delaney CA, Pavlovic D, Hoorens A, Pipeleers DG, Eizirik DL (1997) Cytokines induce deoxyribonucleic acid strand breaks and apoptosis in human pancreatic islet cells. Endocrinology 138:2610-2614

18. Hoorens A, Stange G, Pavlovic D, Pipeleers D (2001) Distinction between interleukin-1-induced necrosis and apoptosis of islet cells. Diabetes 50:551-557

19. Cardozo AK, Kruhoffer M, Leeman R, Orntoft T, Eizirik DL (2001) Identification of novel cytokine-induced genes in pancreatic beta-cells by high-density oligonucleotide arrays. Diabetes 50:909-920

20. Cardozo AK, Proost P, Gysemans C, Chen MC, Mathieu C, Eizirik DL (2003) IL-1beta and IFN-gamma induce the expression of diverse chemokines and IL-15 in human and rat pancreatic islet cells, and in islets from pre-diabetic NOD mice. Diabetologia 46:255-266

21. Lund R, Aittokallio T, Nevalainen O, Lahesmaa R (2003) Identification of novel genes regulated by IL-12, IL-4, or TGFbeta during the early polarization of CD4+ lymphocytes. J Immunol 171:5328-5336

22. Hiscott J, Pitha P, Genin P et al (1999) Triggering the interferon response: the role of IRF-3 transcription factor. J Interferon Cytokine Res 19:1-13

23. Servant MJ, ten Oever B, LePage C et al (2001) Identification of distinct signaling pathways leading to the phosphorylation of interferon regulatory factor 3 . J Biol Chem 276:355-363

24. Sato M, Suemori H, Hata N et al (2000) Distinct and essential roles of transcription factors IRF-3 and IRF-7 in response to viruses for IFN-alpha/beta gene induction. Immunity 13:539548

25. Matsuyama T, Kimura T, Kitagawa M et al (1993) Targeted disruption of IRF-1 or IRF-2 results in abnormal type I IFN gene induction and aberrant lymphocyte development. Cell 75:83-97

26. Taniguchi T, Takaoka A (2002) The interferon-alpha/beta system in antiviral responses: a multimodal machinery of gene regulation by the IRF family of transcription factors. Curr Opin Immunol 14:111-116

27. Marie I, Durbin JE, Levy DE (1998) Differential viral induction of distinct interferon-alpha genes by positive feedback through interferon regulatory factor-7. EMBO J 17:6660-6669

28. Rasschaert J, Liu D, Kutlu B et al (2003) Global profiling of double stranded RNA- and IFN-gamma-induced genes in rat pancreatic beta cells. Diabetologia 46:1641-1657

29. Roulston A, Marcellus RC, Branton PE (1999) Viruses and apoptosis. Annu Rev Microbiol 53:577-628

30. Rewers M, LaPorte RE, Walczak M, Dmochowski K, Bogaczynska E (1987) Apparent epidemic of insulin-dependent diabetes mellitus in Midwestern Poland. Diabetes 36:106-113

31. Wagenknecht LE, Roseman JM, Herman WH (1991) Increased incidence of insulin-dependent diabetes mellitus following an epidemic of Coxsackievirus B5. Am J Epidemiol 133:10241031

32. Kutlu B, Cardozo AK, Darville MI et al (2003) Discovery of gene networks regulating cytokine-induced dysfunction and apoptosis in insulin-producing INS-1 cells. Diabetes 52:27012719 
33. Baudoux P, Carrat C, Besnardeau L, Charley B, Laude H (1998) Coronavirus pseudoparticles formed with recombinant $\mathrm{M}$ and $\mathrm{E}$ proteins induce alpha interferon synthesis by leukocytes. J Virol 72:8636-8643

34. Cerretti DP, Kozlosky CJ, Mosley B et al (1992) Molecular cloning of the interleukin-1 beta converting enzyme. Science 256:97-100

35. Doyle S, Vaidya S, O'Connell R et al (2002) IRF3 mediates a TLR-3/TLR4-specific antiviral gene program. Immunity 17:251263

36. Bradley LM, Asensio VC, Schioetz LK et al (1999) Isletspecific Th1, but not Th2, cells secrete multiple chemokines and promote rapid induction of autoimmune diabetes. J Immunol 162:2511-2520

37. Christen U, McGavern DB, Luster AD, von Herrath MG, Oldstone MB (2003) Among CXCR3 chemokines, IFN-gammainducible protein of $10 \mathrm{kDa}(\mathrm{CXC}$ chemokine ligand (CXCL) 10) but not monokine induced by IFN-gamma (CXCL9) imprints a pattern for the subsequent development of autoimmune disease. J Immunol 171:6838-6845

38. Chin YE, Kitagawa M, Su WC, You ZH, Iwamoto Y, Fu XY (1996) Cell growth arrest and induction of cyclin-dependent kinase inhibitor p21 WAF1/CIP1 mediated by STAT1. Science 272:719-722
39. Chin YE, Kitagawa M, Kuida K, Flavell RA, Fu XY (1997) Activation of the STAT signaling pathway can cause expression of caspase 1 and apoptosis. Mol Cell Biol 17:5328-5337

40. Townsend PA, Scarabelli TM, Davidson SM, Knight RA, Latchman DS, Stephanou A (2004) STAT-1 interacts with p53 to enhance DNA damage-induced apoptosis. J Biol Chem 279:58115820

41. Taniguchi T, Ogasawara K, Takaoka A, Tanaka N (2001) IRF family of transcription factors as regulators of host defense. Annu Rev Immunol 19:623-655

42. Zhang L, Pagano JS (2002) Structure and function of IRF-7. J Interferon Cytokine Res 22:95-101

43. Andrews HN, Mullan PB, McWilliams S et al (2002) BRCA1 regulates the interferon gamma-mediated apoptotic response. J Biol Chem 277:26225-26232

44. Agol VI, Belov GA, Bienz K et al (2000) Competing death programs in poliovirus-infected cells: commitment switch in the middle of the infectious cycle. J Virol 74:5534-5541 